\title{
Pengaruh Konflik Peran, Stress, dan Dukungan Sosial terhadap Komitmen Afektif Organisasi Pegawai Wanita (Studi pada Pegawai Wanita Bank X Banjarmasin)
}

\section{The Effect of Role Conflict, Stress, and Social Support on Female Employee Organizational Commitments}

\author{
Lestari Dwiyanti*), Laila Refiana Said, \& Dahniar \\ Program Magister Manajemen, Fakultas Ekonomi dan Bisnis, Universitas Lambung \\ Mangkurat, Indonesia
}

*Corresponding E-mail: lestaridwiyanti1919 @gmail.com

\begin{abstract}
Abstrak
Penelitian ini bertujuan untuk menganalisis pengaruh konflik peran dan stres pada komitmen afektif karyawan wanita dengan dukungan sosial sebagai variabel moderasi di Bank X di Banjarmasin. Jenis penelitian ini adalah penelitian penjelasan dengan pendekatan kuantitatif. Responden dalam penelitian ini adalah seluruh karyawan wanita di Bank X di Banjarmasin. Teknik pengambilan sampel yang digunakan adalah teknik sampling jenuh. Pengumpulan data menggunakan kuesioner dengan skala likert. Teknik analisis data menggunakan teknik analisis Partial Least Square (PLS) dengan perangkat lunak SmartPLS 3.0. Hasil penelitian menyimpulkan bahwa ada pengaruh negatif yang signifikan dari konflik peran pada komitmen afektif dan ada efek negatif yang signifikan dari stres pada komitmen afektif . Temuan lainnya menunjukkan bahwa dukungan sosial mampu bertindak sebagai variabel pemoderasi pada pengaruh konflik peran dan stress pada komitmen afektif organisasi .
\end{abstract}

Kata Kunci: Konflik Peran, Stres, Dukungan Sosial, Komitmen Afektif.

\begin{abstract}
This study aims to analyze the influence of role conflict and stress on the affective commitment of female employees with social support as a moderating variable in Bank X in Banjarmasin. This type of research is explanatory research with a quantitative approach. Respondents in this study were all female employees of the Bank $X$ in Banjarmasin. The sampling technique used is a saturation sampling technique. Data collection uses a Likert scale scale questionnaire. Data analysis techniques using Partial Least Square (PLS) analysis techniques with SmartPLS 3.0 software. The results of the study concludes that there is a significant negative effect of role conflict on affective commitment and there is a significant negative effect of stress on affective commitment. Other findings indicate that social support is able to act as a moderating variable on the influence of role conflict and stress on organizational affective commitment.
\end{abstract}

Keywords: Role Conflict, Stress, Social Support, Affective Commitment.

How to Cite: Dwiyanti, L. Said, L.R. \& Dahniar. (2019). Pengaruh Konflik Peran, Stress, dan Dukungan Sosial terhadap Komitmen Afektif Organisasi Pegawai Wanita, Jurnal Konsep Bisnis dan Manajemen, 6(1) $: 24-32$ 


\section{PENDAHULUAN}

Manajemen sumber daya manusia (MSDM) merupakan suatu sistem dengan ruang lingkup yang digunakan untuk mengatasi berbagai tantangan dalam rangka mencapai tujuan perusahaan. Ruang lingkup MSDM terbagi 2 yaitu tantangan yang bersifat internal dan yang bersifat eksternal. Tantangan internal yang jelas bagi manajemen SDM terletak pada sifat unik dari sumber daya manusia yang digunakan oleh perusahaan. Hal ini dimaksudkan, agar produktivitas dan penilaian terhadap kualitas output SDM dapat dilakukan dengan mudah. (Zainal, Ramly, Mutis \& Arafa, 2014).

Salah satu permasalahan yang menarik untuk dipelajari dalam bidang ilmu sumber daya manusia adalah komitmen pegawai terhadap organisasi. Hal ini merupakan sikap kerja yang dikehendaki organisasi karena pegawai yang memiliki komitmen diharapkan dapat menunjukkan kesediaan untuk bekerja lebih keras demi mencapai tujuan organisasi dan memiliki hasrat yang lebih besar untuk tetap bekerja di perusahaan (Kreitner \& Kinicki, 2014).

Berbicara tentang peningkatan gangguan terhadap komitmen organisasi berdasarkan teori inhibiting factors salah satunya dapat ditimbulkan adanya role conflict (konflik peran) yang dialami pegawai. Konflik peran bisa berpotensi menyebabkan seorang pegawai mengalami kegagalan dalam mengikuti proses, inkonsisten dan tidak sesuai dengan apa yang diharapkan oleh perusahaan tempatnya bekerja. Hal ini diperoleh dari hasil penelitian oleh Karatepe dan Karadas (2016). Penelitian ini menyoroti sisi lain dari pengaruh konflik peran yaitu pengaruhnya terhadap stres dan kepuasan kerja. Di sisi lain, Ackfeldt dan Malholtra (2013) meneliti tentang pengaruh role stresser or (role conflict, role ambiguity, role overload) terhadap komitmen afektif organisasi. Penelitian terhadap frontliners ini memperoleh hasil role conflict dapat menurunkan tingkat komitmen organisasi pegawai.

Penelitian lainnya oleh Utama dan Sintaasih (2015) terhadap komitmen organisasi dari 67 responden pegawai Bank Mandiri Cabang Veteran Denpasar menemukan hasil bahwa konflik peran yang timbul karena adanya tekanan dari keluarga maupun dari pekerjaan (workfamily conflict) berhubungan negatif signifikan terhadap komitmen organisasi pegawai, sedangkan komitmen organisasi berhubungan negatif signifikan dengan turnover intention pegawai. 
Konflik peran sendiri merupakan signifikan terhadap turnover intention stressor, di mana semakin besar konflik karyawan secara langsung tetapi menjadi peran maka semakin besar pula subjective stress. Secara khusus ditemukan juga bahwa pegawai wanita mengalami konflik peran yang lebih besar dibandingkan pegawai pria (Kremer 2016). Penelitian Kremer juga mengungkapkan bahwa konflik peran bisa menjadi stressor yang merugikan kesehatan psikologis, kinerja dan meningkatkan turnover intention. Beberapa tahun sebelum penelitian Kremer, ada penelitian dari Khetarpal dan Kochar (2005) tentang role stress yaitu stres yang dialami wanita pekerja profesional akibat peran yang dimilikinya. Sehingga, hal ini tentu mengganggu dalam pemenuhan tanggung jawabnya di tempat kerja dan tanggung jawab di keluarga. (Agarwal \& Lenka 2015).

Khusus untuk penelitian terhadap pegawai wanita perbankan yang pernah dilakukan Erdiana dan Eviana (2012) serta Yani, Sudibya dan Rahyuda (2016) memberikan hasil yang berbeda. Penelitian Erdiana dan Eviana memberikan hasil bahwa work family conflict yang dialami oleh pegawai wanita perbankan bisa meningkatkan turnover intention. Adapun hasil penelitian oleh Yani, Sudibya dan Rahyuda (2016 mengemukakan bahwa work family conflict tidak berpengaruh berpengaruh melalui variabel kepuasan kerja.

Beberapa hasil penelitian yang mengulas hubungan antara konflik peran, stres dan keterlibatan dalam pekerjaan. Park dan Jang (2017) mengemukakan bahwa konflik peran di keluarga yang berlebihan menyebabkan stres yang tinggi terutama bagi pegawai yang mempunyai efikasi diri dan keterlibatan dalam pekerjaan yang tinggi di perusahaan. Keterlibatan kerja menurut Hallberg dan Schaufeli (2006) erat kaitannya dengan komitmen organisasi. Salah satu variabel yang mempengaruhi dari keterlibatan dalam pekerjaan adalah komitmen organisasi sebagai salah satu bentuk sikap seorang pegawai terhadap organisasi. Dalam hubungan korelasinya sendiri keterlibatan dalam pekerjaan adalah positif dengan komitmen organisasi artinya semakin tinggi keterlibatan sesorang dalam pekerjaannya maka komitmen organisasinya juga akan meningkat dan begitu juga sebaliknya (Lubakaya, 2014).

Penelitian oleh Saranani (2015) yang meneliti mengenai konflik peran dan pengaruhnya terhadap komitmen organisasional mengemukakan bahwa dahulu organisasi memperlakukan karyawan secara 
individu, tetapi sekarang karyawan diperlakukan sebagai bagian dari kelompok atau tim yang bekerja dalam organisasi dengan tujuan untuk mengoptimalkan kelompok yang ditetapkan sebagai aspek sosial, teknis serta kinerja individu itu sendiri di lingkungan kerja. Riset yang dilakukan oleh Strutton dan Tran (2014) mengenai stres adalah bagaimana cara mengubah stres yang buruk menjadi sesuatu yang baik bagi para pegawai. Penelitian ini menyimpulkan bahwa ketika para manajer menangani stres yang muncul dengan baik dan lebih cekatan, stres malah bisa efektif untuk meningkatkan motivasi pegawai. Diharapkan dengan seiringnya peningkatan motivasi, kinerja pegawai dan perusahaan juga bisa meningkat.

Penelitian mengenai stres dalam hubungannya dengan dukungan sosial dilakukan oleh Yu, Dong, Wang dan An (2016). Penelitian oleh para ahli ini terhadap stres yang dirasakan oleh para guru di Cina ditemukan bahwa apabila tingkat dukungan sosial dirasakan rendah maka semakin besar pula stres yang dirasakan oleh para guru tersebut, begitu juga kondisi sebaliknya.

Banyak penelitan lainnya mengenai dukungan sosial yang dihubungkan dengan variabel-variabel selain stres, antara lain : Lambert, Minor, Wells \& Hogan (2015), Gelderen dan Bik (2016), Adams, King, LA, King, DW (1996), Chiu, Yeh dan Huang (2015), dan Fazio, Gong, Sims dan Yurova (2017). Hasil penelitian para ahli ini mengemukakan pengaruh dari tinggi rendahnya dukungan sosial yang diterima terhadap variabel lainnya.

Penelitian-penelitian sebelumnya memberikan informasi bahwa pegawai wanita lebih berpotensi mengalami konflik peran dan rentan mengalami stres yang lebih tinggi dibandingkan pegawai pria. Tingginya stres yang dialami pekerja wanita terutama yang telah menikah terlebih yang telah mempunyai anak adalah ketika harus membagi waktu dan perhatiannya untuk pekerjaan dan keluarga (Kremer, 2016). Berdasarkan uraian tersebut penelitian ini mencoba membuktikan pengaruh konflik peran dan stres terhadap komitmen afektif organisasi serta dukungan sosial sebagai variabel moderasinya pada pegawai wanita perbankan dengan objek penelitian yaitu Bank X di Banjarmasin.

\section{METODE PENELITIAN}

Penelitian ini adalah penelitian eksplanatori dengan pendekatan kuantitatif. Penelitian ini dilakukan di salah satu Bank di Banjarmasin (Bank X) dengan teknik pengambilan sampel yang digunakan yaitu 
sampling jenuh yaitu seluruh populasi pegawai wanita di bank X Banjarmasin. Jumlah sampel dalam penelitian ini adalah 138 orang pegawai wanita di Bank X. Pengukuran variabel penelitian menggunakan summated scale atau skala Likert (Sugiyono, 2015) dengan menggunakan instrumen penelitian kuesioner tertutup dan terstruktur. Skor pengukuran yang digunakan untuk variabel konflik peran, stress dan dukungan sosial adalah sebagai berikut :Tidak pernah (P) diberi skor nilai 1, Hampir Tidak Pernah (HTP) diberi skor nilai 2, Kadang-kadang (KD), diberi skor nilai 3, Sering (S) diberi skor nilai 4, Sangat sering (SS) diberi skor nilai 5. Adapun untuk variabel komitmen afektif organisasi sebagai berikut : sangat tidak setuju (STS), diberi skor nilai 1 , tidak setuju (TS), diberi skor nilai 2, kurang setuju (KS ), diberi skor nilai 3,Setuju (S), diberi skor nilai 4, sangat setuju (SS) diberi skor nilai 5.

\section{HASIL DAN PEMBAHASAN}

Berdasarkan kuesioner dari keseluruhan responden diperoleh gambaran kondisi reponden sebagai pegawai wanita PT Bank X yang dijadikan obyek penelitian dalam kaitannya dengan variabel yang diteliti antara lain: konflik peran, stres yang dirasakan, dukungan sosial yang diterima dan sikap tentang komitmen afektif pegawai terhadap perusahaan.

Analisis data yang digunakan dalam penelitian ini adalah Structural Equation Model (SEM) dengan metode alternatif Partial Least Square. Menggunakan metode alternatif PLS karena berdasarkan pada pengukuran prediksi yang mempunyai sifat non-parametrik sesuai indikator variabel yang berskala likert 1 sampai 5 (Sugiyono, 2015). Hasil Result for inner weights Model I dan penjelasannya dapat dilihat di Tabel 1.

Tabel 1. Results for Inner Weights Model I

\begin{tabular}{llllll}
\hline & $\begin{array}{l}\text { Original } \\
\text { Sample } \\
(\mathrm{O})\end{array}$ & $\begin{array}{l}\text { Sample } \\
\text { Mean } \\
(\mathrm{M})\end{array}$ & $\begin{array}{l}\text { Standard } \\
\text { Deviation } \\
(\text { STDEV })\end{array}$ & $\begin{array}{l}\mathrm{T} \text { Statistics } \\
(|\mathrm{O} / \mathrm{STDEV}|)\end{array}$ & $\begin{array}{l}\mathrm{P} \\
\text { Values }\end{array}$ \\
\hline DS -> KA & $\mathbf{0 . 3 2 2}$ & 0.324 & 0.054 & 5.958 & 0.000 \\
\hline KP $->$ KA & -0.302 & -0.300 & 0.082 & 3.702 & 0.000 \\
\hline S -> KA & -0.358 & -0.361 & 0.077 & 4.669 & 0.000 \\
\hline
\end{tabular}

Berdasarkan Tabel 1 diketahui nilai t $\quad 3,702$ lebih besar dari t Tabel $( \pm 1,96)$ dan hitung pengaruh konflik peran (KP) koefisien bernilai negatif sebesar -0,302. terhadap komitmen afektif (KA) sebesar 
Jadi konflik peran berpengaruh negatif terhadap komitmen afektif.

Nilai t hitung pengaruh stres (S) terhadap komitmen afektif (KA) sebesar 4,669 lebih besar dari t Tabel $( \pm 1,96)$ dan koefisien bernilai negatif sebesar $-0,358$. Jadi stres berpengaruh negatif terhadap komitmen afektif. Semakin tinggi stres maka semakin rendah komitmen afektif pegawai wanita, sebaliknya semakin rendah stres maka semakin tinggi komitmen afektif pegawai wanita. Nilai t hitung pengaruh dukungan sosial (DS) terhadap komitmen afektif (KA) sebesar 5,958 lebih besar dari t Tabel $( \pm 1,96)$ dan koefisien bernilai positif sebesar 0,322. Jadi dukungan sosial berpengaruh positif terhadap komitmen afektif. Semakin tinggi dukungan sosial maka semakin tinggi komitmen afektif pegawai wanita, sebaliknya semakin rendah dukungan sosial maka semakin rendah komitmen afektif pegawai wanita.

Tabel 2. Full Model Analisis PLS Pengujian Moderasi Menggunakan Product Indicator Approach

\begin{tabular}{llllll}
\hline & $\begin{array}{l}\text { Original } \\
\text { Sample (0) }\end{array}$ & $\begin{array}{l}\text { Sample } \\
\text { Mean (M) }\end{array}$ & $\begin{array}{l}\text { Standard } \\
\text { Deviation } \\
\text { (STDEV) }\end{array}$ & $\begin{array}{l}\text { T Statistics } \\
(\mid \text { O/STDEV|) }\end{array}$ & P Values \\
\hline DS -> KA & 0.116 & 0.118 & 0.036 & 3.217 & 0.001 \\
\hline DS*KP -> KA & 0.278 & 0.286 & 0.076 & 3.639 & 0.000 \\
\hline DS*S -> KA & 0.354 & 0.347 & 0.080 & 4.430 & 0.000 \\
\hline KP -> KA & -0.132 & -0.129 & 0.066 & 2.013 & 0.045 \\
\hline S -> KA & -0.221 & -0.222 & 0.063 & 3.490 & 0.001 \\
\hline
\end{tabular}

Tabel 2. yang merupakan tabel dari full model analisis PLS pengujian moderasi dengan menggunakan product indicator approach dapat diketahui bahwa dalam penelitian ini untuk moderasi yang terjadi adalah quasi moderasi. Dikatakan quasi moderasi karena dalam penelitian ini variabel dukungan sosial yang memoderasi hubungan antara konflik peran dengan komitmen afektif dan stres dengan komitmen afektif menjadi variabel prediktor (Solimun, 2011 hal.33). Dari olah data melalui PLS ,diperolah hasil dukungan sosial berpengaruh terhadap komitmen afektif yaitu sebesar 3,217 atau lebih besar dari t Tabel $( \pm 1,96)$ dan memoderasi interaksi antara dukungan sosial dan konflik peran serta interaksi antara dukungan sosial dan stres yang berpengaruh terhadap terhadap komitmen afektif yaitu masing-masing sebesar 3,639 dan 4,430 atau lebih besar dari t Tabel $( \pm 1,96)$.

Berdasarkan Tabel 2 diketahui nilai t hitung pengaruh variable interaksi dukungan sosial dengan konflik peran terhadap komitmen afektif sebesar 3,639 lebih besar 
dari $t$ Tabel $( \pm 1,96)$ dengan koefisien 0,278. Jadi dukungan sosial dapat menaikkan atau menurunkan pengaruh konflik peran terhadap komitmen afektif, semakin tinggi dukungan sosial yang didapat pegawai wanita maka dapat menurunkan pengaruh konlik peran terhadap komitmen afektif pegawai wanita. Sebaliknya semakin rendah dukungan sosial yang dirasakan oleh pegawai wanita maka semakin menaikkan pengaruh konflik peran terhadap komitmen afektif pegawai wanita.

Berdasarkan Tabel 2 diketahui nilai t hitung pengaruh variabel interaksi dukungan sosial dengan stres terhadap komitmen afektif sebesar 4,430 lebih besar dari $t$ Tabel $( \pm 1,96)$ dengan koefisien 0,354 . Jadi dukungan sosial dapat menaikkan atau menurunkan hubungan antara stres dengan komitmen afektif. Semakin tinggi dukungan sosial yang dirasakan oleh pegawai wanita maka semakin menaikkan pengaruh stress terhadap komitmen afektif pegawai wanita. Sebaliknya semakin rendah dukungan sosial yang dirasakan pegawai wanita maka semakin menaikkan pengaruh stres terhadap komitmen afektif pegawai wanita.

\section{SIMPULAN}

Berdasarkan hasil analisis data yang dilakukan di PT Bank X Banjarmasin mengenai pengaruh konflik peran dan stres terhadap komitmen afektif dengan dukungan sosial sebagai variabel pemoderasi, maka dapat disimpulkan sebagai berikut:

1. Konflik peran berpengaruh terhadap komitmen afektif pegawai wanita PT Bank X Banjarmasin.

2. Stres berpengaruh terhadap komitmen afektif pegawai wanita PT Bank X Banjarmasin.

3. Dukungan sosial terbukti memoderasi hubungan konflik peran terhadap komitmen afektif pegawai wanita PT Bank X Banjarmasin.

4. Dukungan sosial terbukti memoderasi hubungan antara stres terhadap komitmen afektif pada pegawai wanita PT Bank X Banjarmasin.

Saran-saran yang dapat diberikan berdasarkan hasil, penelitian adalah sebagai berikut:

1. Adanya komunikasi dan hubungan yang terjalin harmonis antara pihak manajemen Bank X Banjarmasin dengan pihak keluarga pegawainya, seperti melalui kegiatan familly gathering secara rutin dengan mengundang keluarga pegawai (suami/-istri dan anak anak) untuk berhadir bergabung bersama pegawai dan manajemen atau acara ramah tamah antara pihak manajemen perusahaan dengan keluarga diberbagai kesempatan pegawai, di mana dalam acara tersebut bisa dimanfaatkan sebagai ajang silaturahmi agar pihak keluarga juga 
ikut merasakan sebagai bagian dari keluarga besar perusahaan. Peru-sahaan dan pihak keluarga pegawai bisa saling berkomunikasi dan berbagi informasi mengenai berbagai hal.

2. Dukungan sosial dari rekan kerja yang terbukti paling tinggi dirasakan oleh para pegawai. Dukungan sosial dari pihak Manajemen perusahaan khususnya supervisor (atasan langsung) pegawai wanita dapat lebih ditingkatkan untuk mengurangi

\section{DAFTAR PUSTAKA}

Ackfeldt, Anna-Lena \& Malholtra, Neeru, 2013, Revisiting the role stress- commitment relationship. Can managerial interventions help, European Journal of Marketing Vol. 47 No. 3/4, 2013. Emerald Insight. pp. 353-374.

Adams, Gary.A, King, Lynda A, King, Daniel W, 1996, Relationships of Job and Family Involvement, Family Social Support, and Work-Family Conflict With Job and Life Satisfaction. Journal of Applied Psychology 1996, Vol. 81, No. 4, 411-42. Central Michigan University.hal. 411-420.

Agarwal, Sucheta \& Lenka, Usha , 2015, Study on work-life balance of women entrepreneurs review and research agenda, Industrial and Commercial Training, Vol. 47 Iss 7, Emerald Insight. pp. $356-362$.

Fazio, John, Gong, Baiyun, Sims, Randi \& Yurova, Yuliya, (2017), The role of affective commitment in the relationship between social support and turnover intention ", Management Decision, Vol. 55 Iss 3 pp.512-525 Emerald Insight.

Gelderen, Benjamin R. V \& Bik, Leonie.W, 2016, Affective organizational commitment, work engagement and service performance among police officers,An International Journal of Police Strategies \&Management, Issue: 1, Emerald Insight,pp.206-222.

Hallberg, Ulrika E \& Schaufeli, Wilmar B, 2006, Same Same But Different? Can Work Engagement Be Discriminated from Job Involvement and Organizational Commitment? Hogrefe \& Huber Publishers European Psychologist, Vol. 11(2), hal:19-127. dampak yang ditimbulkan oleh konflik peran dan stres. Dukungan sosial dari perusahaan dapat dilakukan dengan Pihak Manajemen perusahaan secara konsisten dan menyeluruh dalam hal memberikan dukungan baik dalam lingkup pekerjaan maupun lingkup pribadi pegawai dengan memperkuat sistem, kebijakan dan fasilitas yang dapat meningkatkan rasa nyaman bagi para pegawai khususnya pada pegawai wanita.

Karatepe, Osman \& Karadas, Georgiana, 2016, Service employees' fit, work-family conflict, and work engagement, Journal of Services Marketing, Vol. 30 Iss 5. Emerald Insight. pp.554-566

Khetarpal, A \& Kochar, G, 2005, Role Stress And Preventive Management. The Internet Journal of World Health and Societal Politics. Volume 3 Number 1, ISPUB.COM.pp.1-5

Kremer, Inbar, 2016, The relationship between school-work-family-conflict, subjective stress, and burnout,Journal of Managerial Psychology, Emerald Insight.pp.1-32

Lestari, Sri, 2012, Psikologi Keluarga. Kencana Prenadamedia Group. Yogyakarta.

Lubakaya, Christopher Wanyonyi, 2014, Factors Affecting Job Involvement in an Organization : A Case of Nzoia Sugar Company Limited. International Journal Of Innovative Research\& Development, Vol.3 Issue 6www.Ijird.com.

Luthans, Fred. 2006. Perilaku Organisasi, (Alih Bahasa V.A Yuwono, dkk), Edisi. Bahasa Indonesia, Yogyakarta: ANDI.

Netemeyer, Richard G. Boles, James S. \& McMurrian, Robert, 1996, Development and Validation of Work-Family Conflict and Family-Work Conflict Scales. Journal Of Applied Psychology Vol.81 No.4, 400-410. American Psychological Association, Inc. USA.

Park, Rhokeun \& Jang, So Jung. 2017, Family role overload's relationship with stress and satisfaction, Journal of Managerial Psychology, Vol. 32 Iss 1, Emerald Insight.pp.61-74

Setyowati, Reino \& Riyono,Bagus, 2003, Pebedaan Aspirasi Karir Antara Wanita yang Sudah Menikah dan yang Belum Menikah Pada 
Lestari Dwiyanti, Laila Refiana Said \& Dahniar, Pengaruh Konflik Peran, Stress, dan Dukungan Sosial terhadap Komitmen Afektif Organisasi Pegawai Wanita

Pegawai Negeri Sipil. PSIKOLOGIKA Nomor 16 tahun VIII Juli.

Sugiyono, 2015, Metode Penelitian Manajemen. Alfabeta. Bandung.

Suriastini, Ni Wayan, 2006, Hubungan Umur Dengan Perubahan Pekerjaan. Populasi: Suatu Aplikasi Metaanalisis Dengan Ukuran Sampel, ISSN:0853-0262,

Yani, Ni Wayan M.S.A, Sudibya, I Gde Adnyana \& Rahyuda, Agoes Ganesha, 2016, Pengaruh Work-Family Conflict dan Stres Kerja Terhadap Kepuasan Kerja dan Turnover Intention Karyawan Wanita, E-Jurnal Ekonomi dan Bisnis Universitas Udayana, 5.3.hal.629658.
Yu, Guoliang, Dong, Yang, Wang, Qi \& An, Ran , 2016, Reducing teacher stress: improving humanized management of Chinese teachers. Journal of Chinese Human Resource Management, Vol. 7 Issue: 2, , Emerald Insight.pp.82-99.

Zainal, V.R, Ramly, Mansyur, Mutis, Thoby \& Arafah, Willy, 2014, Manajemen Sumber Daya Manusia Untuk Perusahaan Dari Teori Ke Praktik.PT. RajaGrafindo Persada. 